\author{
GRZEGORZ DoBrowolsKI ${ }^{1}$
}

\title{
Szczególne „substytuty” planowania przestrzennego
}

I. Kształtowanie ładu przestrzennego, zgodnie $\mathrm{z}$ art. 2 pkt 1 ustawy $\mathrm{z}$ dnia 27 marca 2003 r. o planowaniu i zagospodarowaniu przestrzennym ${ }^{2}$ (dalej jako „u.p.z.p”), polega na takim ukształtowaniu przestrzeni, które tworzy harmonijną całość oraz uwzględnia w uporządkowanych relacjach wszelkie uwarunkowania i wymagania funkcjonalne, społeczno-gospodarcze, środowiskowe, kulturowe oraz kompozycyjno-estetyczne.

Osiągnięcie tak rozumianego celu może następować za pomocą różnego rodzaju instrumentów. Podstawową rolę w tym zakresie odgrywa miejscowy plan zagospodarowania przestrzennego. Zgodnie z art. 4 ust. 1 u.p.z.p. określa on przeznaczenie terenu, rozmieszczenie inwestycji celu publicznego oraz sposoby zagospodarowania i warunków zabudowy terenu.

W analizowanym zakresie (art. 15 ust. 2 u.p.z.p.) plan określa między innymi:

- przeznaczenie terenów oraz linie rozgraniczające tereny o różnym przeznaczeniu lub różnych zasadach zagospodarowania,

- zasady ochrony i kształtowania ładu przestrzennego,

- wymagania wynikające z potrzeb kształtowania przestrzeni publicznych,

- zasady kształtowania zabudowy oraz wskaźniki zagospodarowania terenu, maksymalną i minimalną intensywność zabudowy jako wskaźnik powierzchni całkowitej zabudowy w odniesieniu do powierzchni działki budowlanej, minimalny udział procentowy powierzchni biologicznie czynnej w odniesieniu do powierzchni działki budowlanej, maksymalną wysokość zabudowy, minimalną liczbę miejsc do parkowania i sposób ich realizacji oraz linie zabudowy i gabaryty obiektów,

- zasady modernizacji, rozbudowy i budowy systemów komunikacji i infrastruktury technicznej. 
W przypadku obszarów morskich wód wewnętrznych, morza terytorialnego i wyłącznej strefy ekonomicznej przeznaczenie terenu, rozmieszczenie inwestycji celu publicznego oraz sposób zagospodarowania i warunki zabudowy terenu określa się na podstawie przepisów ustawy z dnia 21 marca 1991 r. o obszarach morskich Rzeczypospolitej Polskiej i administracji morskiej. ${ }^{3}$ Mowa tu o przyjmowanym $w$ drodze rozporządzenia ministra właściwego do spraw gospodarki morskiej oraz ministra właściwego do spraw rozwoju regionalnego w porozumieniu z ministrami właściwymi do spraw: środowiska, gospodarki wodnej, kultury i ochrony dziedzictwa narodowego, rolnictwa, rybołówstwa, transportu, wewnętrznych oraz Ministrem Obrony Narodowej, planie zagospodarowania przestrzennego morskich wód wewnętrznych, morza terytorialnego i wyłącznej strefy ekonomicznej (art. 37a ustawy o obszarach morskich Rzeczypospolitej Polskiej i administracji morskiej). W przypadku braku takiego planu pozwolenie na wznoszenie i wykorzystywanie sztucznych wysp, konstrukcji i urządzeń w polskich obszarach morskich wydaje minister właściwy do spraw gospodarki morskiej.

II. W obecnym stanie prawnym planowanie przestrzenne nie ma charakteru obligatoryjnego. Stąd organy gmin nie przystępują często do procedury planistycznej, ograniczając się jedynie do uchwalania studiów uwarunkowań przestrzennego zagospodarowania gminy. Bez wątpienia przyczyną tej sytuacji jest znaczny koszt opracowania projektu mpzp., który wynosi przynajmniej kilkanaście tysięcy złotych. ${ }^{4}$ Jednak w przypadku obszarów o intensywnej zabudowie może on być znacząco większy. Przykładem może tu być koszt opracowania projektu miejscowego planu zagospodarowania przestrzennego fragmentu Śródmieścia Katowic w rejonie ulic Kościuszki i Mikołowskiej, który wyniósł 137311 zł. $^{5}$

W przypadku braku obowiązującego miejscowego planu zagospodarowania przestrzennego sposób zagospodarowania oraz warunki zabudowy terenu są okreŚlane (art. 4 ust. 2 u.p.z.p.) poprzez wydanie decyzji o:

- lokalizacji inwestycji celu publicznego,

- warunkach zabudowy,

noszących zbiorczą nazwę decyzji o warunkach zabudowy i zagospodarowania terenu (dalej ,w.z.z.t.”).

Wydawana zasadniczo przez organ wykonawczy gminy (w przypadku inwestycji celu publicznego ${ }^{6}$ o znaczeniu krajowym i wojewódzkim w uzgodnieniu z mar-

Dz.U. z 2003 r. Nr 153, poz. 1502 ze zm.

Por. http://www.lubicz.pl/redir,1495?wiecej=4661 ; http://bip.izabelin.pl/bip/przetargi/WYNIKI_2010/06-Wybor_ plany.pdf

5 http://bip.um.katowice.pl/zamowienia_podglad.php?t=1220567928\&ido=1290588835
6 Pod pojęciem inwestycji celu publicznego, w świetle art. 2 pkt 5 u.p.z.p., należy rozumieć działania o znaczeniu lokalnym (gminnym) i ponadlokalnym (powiatowym, wojewódzkim i krajowym), a także krajowym (obejmują- 
szałkiem województwa ${ }^{7}$ ), decyzja o lokalizacji inwestycji celu publicznego określa szereg wymagań dotyczących kształtowania przestrzeni, niezbędnych do realizacji dalszych etapów procesu inwestycyjnego (przede wszystkim koniecznych do uzyskania pozwolenia na budowę). Zawiera wskazanie (art. 54 u.p.z.p.):

1) rodzaju inwestycji;

2) warunków i szczegółowych zasad zagospodarowania terenu oraz jego zabudowy wynikających z przepisów odrębnych,

3) linii rozgraniczających teren inwestycji, wyznaczonych na mapie w odpowiedniej skali.

Podobnie sytuacja przedstawia się w przypadku decyzji o warunkach zabudowy. Zgodnie z art. 59 u.p.z.p. jest ona wymagana w przypadku zmiany zagospodarowania terenu $\mathrm{w}$ razie braku planu miejscowego, polegającej na budowie obiektu budowlanego lub wykonaniu innych robót budowlanych, a także zmiany sposobu użytkowania obiektu budowlanego lub jego części, czy wreszcie zmiany zagospodarowania terenu, która nie wymaga pozwolenia na budowę, z wyjątkiem tymczasowej, jednorazowej zmiany zagospodarowania terenu, trwającej do roku.

Szczegółowo przedmiot decyzji o warunkach zabudowy określa rozporządzenie Ministra Infrastruktury z dnia 26 sierpnia 2003 r. w sprawie sposobu ustalania wymagań dotyczących nowej zabudowy i zagospodarowania terenu w przypadku braku miejscowego planu zagospodarowania przestrzennego. ${ }^{8}$ Powinna ona zawierać wymagania dotyczące nowej zabudowy i zagospodarowania terenu w przypadku braku miejscowego planu zagospodarowania przestrzennego, w tym wymagania dotyczące ustalania:

- linii zabudowy,

- wielkości powierzchni zabudowy w stosunku do powierzchni działki albo terenu,

- szerokości elewacji frontowej,

- wysokości górnej krawędzi elewacji frontowej, jej gzymsu lub attyki, geometrii dachu (kąta nachylenia, wysokości kalenicy i układu połaci dachowych).

Już pobieżna analiza treści decyzji o warunkach zabudowy i zagospodarowania terenu i porównanie do treści miejscowego planu zagospodarowania przestrzennego pozwalają stwierdzić, iż ich przedmiot jest bardzo zbliżony. Inaczej mówiąc, decy-

cym również inwestycje międzynarodowe i ponadregionalne), bez względu na status podmiotu podejmującego te działania oraz źródła ich finansowania, stanowiące realizację celów, o których mowa w art. 6 ustawy z dnia 21 sierpnia 1997 r. o gospodarce nieruchomościami (Dz.U. z 2010 r. Nr 102, poz. 651 ze zm.).

7 Jeśli inwestycja ma być realizowana na terenie zamkniętym, decyzja jest wydawana przez wojewodę

8 Dz.U. Nr 164, poz. 1588. 
zja i plan określają sposób zagospodarowania oraz warunki zabudowy terenu, przy czym pierwsza ma postać rozstrzygnięcia w sprawie indywidualnej, drugi zaś w formę aktu generalnego będącego prawem miejscowym.

Powyższe cechy decyzji o warunkach zabudowy i zagospodarowania terenu powodują, iż jest ona czasem określana mianem „substytutu” planu miejscowego. ${ }^{9}$ Koncepcja „,substytutu” planu miejscowego została również zaakceptowana w orzecznictwie sądowoadministracyjnym. Warto tu wspomnieć choćby wyrok WSA w Poznaniu z dnia 24 listopada 2011 r. (IV SA/Po 573/11), gdzie Sąd stwierdził, iż ,skoro plan miejscowy musi być zgodny z ustaleniami studium (art. 20 u.p.z.p.), a decyzja o warunkach zabudowy jest surogatem (substytutem) mpzp., to wydaje się być oczywiste, że także decyzja o warunkach zabudowy musi być zgodna ze studium". ${ }^{10}$

Pojawiają się jednak poglądy zupełnie odmienne. Można tu przytoczyć tezę wyroku WSA w Gliwicach z dnia 3 grudnia 2010 r. (II SA/Gl 545/10), gdzie Sąd uznał, że „decyzja o warunkach zabudowy nie stanowi substytutu planu miejscowego na danym obszarze chociażby dlatego, że nie powstaje ona w wyniku jakiejkolwiek procedury planistycznej. Decyzje o warunkach zabudowy nie tworzą porządku prawnego i nie mają charakteru konstytutywnego. Stanowią szczegółową urzędową informację o tym, jaki obiekt i pod jakimi warunkami inwestor może na danym terenie wybudować bez obrazy przepisów prawa".

Nie wdając się w spory terminologiczne, na potrzeby niniejszej publikacji można jednak przyjąć, iż w znaczeniu przedmiotowym (w odniesieniu do przedmiotu i skutków) określenie „substytut mpzp.” do pewnego stopnia jest uzasadnione.

III. Określenie warunków niektórych kategorii przedsięwzięć (zwłaszcza stanowiących inwestycje celu publicznego) w drodze decyzji o warunkach zabudowy terenu w niektórych przypadkach może okazać się jednak niemożliwe albo przynajmniej bardzo utrudnione. Akt taki może zostać wydany w przypadku, gdy na danym terenie brak obowiązującego mpzp. Gdy plan zaś istnieje, a planowana inwestycja (przedsięwzięcie) nie jest z nim zgodne, to przy stosowaniu ogólnych zasad określonych w ustawie o planowaniu i zagospodarowaniu przestrzennym jedynym rozwiązaniem jest zmiana planu (najczęściej również studium), co jest procedurą długotrwałą, zwłaszcza że wymaga przeprowadzenia najczęściej strategicznej oceny

Por. A. Barczak, Zadania samorządu terytorialnego w ochronie środowiska. Warszawa 2006, s. 87; H. Izdebski, A. Nelicki, I. Zachariasz, Zagospodarowanie przestrzenne. Polskie prawo na tle standardów demokratycznego państwa prawnego, Warszawa 2007, s. 52; J. Goździewicz-Biechońska, Decyzja o warunkach zabudowy i zagospodarowania terenu (cechy szczególne), „Państwo i Prawo” 2010, nr 2, s. 95-108; L.J. Kamiński, Decyzja o lokalizacji inwestycji publicznej, „Wspólnota” 2006, nr 30; A. Ostrowska, Glosa do wyroku NSA z dnia 22 grudnia 2009 r., II OSK 1951/08, „Samorząd Terytorialny” 2010, nr 11, s. 77 i nast. 
oddziaływania na środowisko. ${ }^{11}$ Niezależnie od tego realizacja części przedsięwzięć jest uzależniona od dokonania wywłaszczeń nieruchomości czy ich scaleń. Określenie lokalizacji niektórych kategorii przedsięwzięć (związanych choćby z energetyką jądrową czy liniami kolejowymi) wymaga określenia bardzo szczegółowych wymagań technicznych czy zakresu prowadzonych prac.

Stąd też, w celu umożliwienia realizacji niektórych inwestycji ustawodawca zdecydował się na wprowadzenie szczegółowych zasad realizacji poszczególnych ich kategorii. Następuje to wedle reguł ustalonych w tzw. „specustawach”. Wydane na ich podstawie decyzje (zezwolenia na realizację inwestycji) określają szczególny tryb lokalizacji zamierzeń, często wyłączając ogólne zasady przewidziane ustawą o planowaniu i zagospodarowaniu przestrzennym, zatwierdzają projekty podziału nieruchomości czy wreszcie regulują zagadnienia związane z uzyskaniem odpowiednich tytułów prawnych do nieruchomości. Warto zwrócić wreszcie uwagę, iż w odniesieniu do wydawania części wspomnianych zezwoleń została wprowadzona szczególna procedura ich wydawania, gdzie ograniczono między innymi niektóre uprawnienia stron na przykład w zakresie możliwości wzruszania decyzji ostatecznych.

$\mathrm{Z}$ analizowanego punktu widzenia decyzje zezwalające na realizację inwestycji o charakterze publicznym można podzielić na dwie grupy. Pierwszą, odwołując się do terminologii W. Radeckiego, można określić jako decyzje (pozwolenia) „budowlane". Określają one przede wszystkim lokalizację inwestycji (teren i warunki realizacji) oraz stanowią zezwolenie na jej realizację. W tym zakresie pełnią zatem funkcję zarówno w.z.z.t. jak i pozwolenia na budowę. Druga grupa decyzji (które można by określić mianem ,lokalizacyjnych”) służy, w analizowanym zakresie, wskazaniu miejsca realizacji przedsięwzięcia oraz określeniu jego podstawowych parametrów.

IV. Najbardziej znanym (a i najczęściej stosowanym) rozstrzygnięciem zaliczanym do pierwszej z wyżej wskazanych grup jest wydawana na podstawie ustawy z dnia 10 kwietnia 2003 r. o szczególnych zasadach przygotowania i realizacji inwestycji w zakresie dróg publicznych ${ }^{12}$ decyzja o zezwoleniu na realizację inwestycji drogowej. Stanowi ona instrument upraszczający procedury związane z lokalizacją dróg krajowych, określeniem warunków ich realizacji, czy wreszcie uzyskaniem odpowiednich tytułów prawnych do nieruchomości w granicach projektowanej drogi. Decyzja o zezwoleniu na realizację inwestycji drogowej rozstrzyga zarówno w przedmiocie lokalizacji drogi publicznej, jak i stanowi zezwolenie na realizację (w istocie pozwolenie na budowę) samego przedsięwzięcia. Przy jej wydawaniu nie

Por. G. Dobrowolski, Rola ocen oddziaływania na środowisko w procesie podejmowania przedsięwzięć inwestycyjnych, (w:) Gospodarowanie przestrzenią „nad” i „pod” gruntem. XX Krajowa konferencja rzeczoznawców majątkowych. Katowice 2011, s. 167-178. 
stosuje się również przepisów ustawy o planowaniu i zagospodarowaniu przestrzennym. ${ }^{13}$ Analizowana decyzja określa także szereg wymagań dotyczących między innymi powiązania drogi z innymi drogami publicznymi, określeniem ich kategorii, warunki wynikające z potrzeb ochrony środowiska, ochrony zabytków i dóbr kultury współczesnej oraz potrzeb obronności państwa czy wreszcie wskazuje nieruchomości lub ich części, według katastru nieruchomości, które stają się własnością Skarbu Państwa lub właściwej jednostki samorządu terytorialnego (art. 11f ustawy).

Drugim przykładem decyzji „budowlanej” jest wydawana na podstawie ustawy z dnia 12 lutego 2009 r. o szczególnych zasadach przygotowania i realizacji inwestycji w zakresie lotnisk użytku publicznego ${ }^{14}$ decyzja o zezwoleniu na realizację inwestycji w zakresie lotniska użytku publicznego. Dotyczy ona lotniska użytku publicznego rozumianego jako „lotnisko otwarte dla wszystkich statków powietrznych w terminach i godzinach ustalonych przez zarządzającego tym lotniskiem i podanych do publicznej wiadomości". ${ }^{15}$

Uzyskanie zezwolenia na realizację inwestycji w zakresie lotniska użytku publicznego jest równoznaczne z uzyskaniem decyzji o warunkach zabudowy i zagospodarowania terenu oraz pozwolenia na budowę (art. 14 ustawy). Niezależnie od powyższych, decyzja określa między innymi warunki (art. 8 ust. 1 ustawy) dotyczące powiązania lotniska $\mathrm{z}$ drogami publicznymi, wynikające $\mathrm{z}$ potrzeb ochrony środowiska, ochrony dóbr kultury oraz potrzeb obronności państwa, czy dotyczące ochrony uzasadnionych interesów osób trzecich. Jednocześnie zatwierdza ona konieczne projekty podziału nieruchomości (art. 9 ustawy).

Warto tu wspomnieć jeszcze o pozwoleniu na realizację inwestycji w rozumieniu przepisów ustawy z dnia 8 lipca 2010 r. o szczególnych zasadach przygotowania do realizacji inwestycji w zakresie budowli przeciwpowodziowych. ${ }^{16}$ Stanowi ona instrument służący zapewnieniu realizacji inwestycji w zakresie budowli przeciwpowodziowych. Pod pojęciem tych ostatnich, zgodnie z art. 2 pkt 1 ustawy o szczególnych zasadach przygotowania do realizacji inwestycji w zakresie budowli przeciwpowodziowych, należy rozumieć: kanały ulgi, poldery przeciwpowodziowe, stopnie wodne i zbiorniki retencyjne posiadające retencję powodziową, suche zbiorniki przeciwpowodziowe, wały przeciwpowodziowe, wrota przeciwsztormowe, wrota przeciwpowodziowe, kierownice w ujściach rzek do morza oraz budowle ochrony przed powodzią morską - wraz z obiektami związanym z nimi funkcjonalnie.

13 Por. W. Radecki, Oceny oddziaływania na środowisko, (w:) Podstawy teoretyczne zintegrowanej ochrony prawnej środowiska, Wrocław 2010, s. 196.

Art. 54 ust. 2 ustawy z dnia 3 lipca 2002 r. Prawo lotnicze Dz.U. z 2006 r. Nr 100, poz. 696 ze zm.

Dz.U. Nr 143, poz. 963. 
Uzyskanie decyzji o pozwoleniu na realizację inwestycji jest równoznaczne z uzyskaniem decyzji o warunkach zabudowy (decyzji o ustaleniu lokalizacji inwestycji celu publicznego) oraz pozwolenia na budowę. Określa ona między innymi (art. 9 ustawy) wskazanie linii rozgraniczających teren przedsięwzięcia, określenie warunków technicznych jego realizacji, a także warunki wynikające z potrzeb ochrony środowiska i ochrony zabytków, czy też wymagania dotyczące ochrony interesów osób trzecich. Jednocześnie zatwierdza ona konieczne projekty podziału nieruchomości i projekt budowlany.

V. Wśród aktów administracyjnych zaliczanych do drugiej grupy (decyzji „lokalizacyjnych") można wskazać cały szereg rozstrzygnięć określających lokalizację oraz warunki realizacji przedsięwzięcia i będących podstawą do wydania pozwolenia na budowę.

Pierwszym przykładem może tu być decyzja o ustaleniu lokalizacji linii kolejowej - wydawana na podstawie ustawy z dnia 28 marca 2003 r. o transporcie kolejowym. ${ }^{17}$ Stanowi ona jeden z elementów szczególnego trybu przygotowania inwestycji dotyczących linii kolejowych o znaczeniu państwowym. Co ważne, może być ona wydawana na wniosek tylko jednego podmiotu, którym są PKP Polskie Linie Kolejowe S.A. (art. 9o ustawy o transporcie kolejowym).

Decyzja o lokalizacji linii kolejowej przede wszystkim określa lokalizację przedsięwzięcia, przy czym nie stosuje się przy jej wydawaniu przepisów ustawy o planowaniu i zagospodarowaniu przestrzennym (art. 9a-d ust. 2 ustawy). Zgodnie $\mathrm{z}$ art. 40a ustawy Prawo budowlane, ,ilekroć w przepisach niniejszego rozdziatu jest mowa o decyzji o warunkach zabudowy i zagospodarowania terenu, rozumie się przez to także decyzję o ustaleniu lokalizacji linii kolejowej w rozumieniu ustawy z dnia 28 marca 2003 r. o transporcie kolejowym". Wspomniana decyzja wywiera wreszcie również szereg innych skutków zarówno w zakresie określenia warunków realizacji inwestycji, jak i w zakresie stosunków własnościowych na terenie, gdzie ma być realizowana.

Drugim aktem stanowiącym swojego rodzaju odpowiednik decyzji o warunkach zabudowy i zagospodarowania terenu jest decyzja o ustaleniu lokalizacji przedsięwzięć Euro 2012 - wydawana na podstawie ustawy z dnia 7 września 2007 r. o przygotowaniu finałowego turnieju Mistrzostw Europy w Piłce Nożnej UEFA EURO 2012. ${ }^{18}$ Jej specyfiką jest przede wszystkim zakres przedmiotowy obowiązku jej uzyskania. Dotyczy bowiem przedsięwzięć Euro 2012, niezbędnych do przeprowadzenia w Polsce finałowego turnieju Mistrzostw Europy w Piłce Nożnej UEFA EURO 2012. Ich katalog zawiera rozporządzenie Rady Ministrów z dnia 29 grud- 
nia 2009 r. w sprawie wykazu przedsięwzięć Euro 2012. ${ }^{19}$ Warto zwrócić tu uwagę, iż określenie „przedsięwzięcia EURO 2012” jest bardzo szerokie. W świetle wspomnianego rozporządzenia do tej kategorii zaliczono między innymi budowę Inteligentnego Systemu Transportu „ITS Wrocław”, rozwój szybkiej kolei miejskiej w Trójmieście, budowę Europejskiego Centrum Solidarności w Gdańsku czy wreszcie dostosowanie laboratorium epidemiologicznego Wojewódzkiej Stacji Sanitarno-Epidemiologicznej w Katowicach do prowadzenia specjalistycznej diagnostyki chorób wysoce zakaźnych.

Decyzja o ustaleniu lokalizacji przedsięwzięć Euro 2012 określa lokalizację przedsięwzięć. Zgodnie z art. 25 ust. 4 cytowanej ustawy „ilekroć w przepisach prawa budowlanego jest mowa o decyzji o warunkach zabudowy i zagospodarowania terenu, rozumie się przez to także decyzję o ustaleniu lokalizacji przedsięwzięcia Euro 2012. W odniesieniu do wydania analizowanego aktu ustawodawca wyłączył, co do zasady, stosowanie przepisów o planowaniu i zagospodarowaniu przestrzennym. Decyzja ta określa również między innymi linie rozgraniczające teren przedsięwzięcia, warunki techniczne jego realizacji, a także warunki wynikające z potrzeb ochrony środowiska i ochrony zabytków, czy też wymagania dotyczące ochrony interesów osób trzecich. Jednocześnie zatwierdza ona konieczne projekty podziału nieruchomości (art. 24 ustawy). ${ }^{20}$

Kolejnym wartym wspomnienia aktem jest decyzja o ustaleniu lokalizacji inwestycji w zakresie terminalu, wydawana na podstawie ustawy z dnia 24 kwietnia 2009 r. o inwestycjach w zakresie terminalu regazyfikacyjnego skroplonego gazu ziemnego w Świnoujściu. ${ }^{21}$ Pod pojęciem tej inwestycji należy rozumieć terminal regazyfikacyjny skroplonego gazu ziemnego w Świnoujściu wraz z instalacjami, urządzeniami i obiektami niezbędnymi dla jego uruchomienia i funkcjonowania (art. 1 ust. 2 pkt 1 ustawy). W szczególności dotyczy to (art. 2 ust. 2 ustawy):

- budowy infrastruktury zapewniającej dostęp do portu zewnętrznego, w tym falochronu, toru wodnego, obrotnicy oraz oznakowania nawigacyjnego związanego z wymienioną infrastrukturą,

- poszerzenia istniejącego toru wodnego do Świnoujścia,

- przebudowy istniejącego falochronu w Świnoujściu,

- infrastruktury portowej, w tym stanowiska statkowego wyposażonego w urządzenia cumownicze, odbojowe i nawigacyjne, a także infrastruktury umożliwiającej zamontowanie instalacji do przesyłu gazu i poboru wody z morza,

20 Ł. Makowski, P. Warzel, Postępowanie administracyjne w realizacji przedsięwzięć Euro 2012, (w:) Nowe problemy badawcze w teorii prawa administracyjnego, red. J. Boć, A. Chajbowicz, Wrocław 2009, s. 841-843. 
- gazociągu Świnoujście-Szczecin, łączącego terminal z systemem przesyłowym, wraz z infrastrukturą niezbędną do jego obsługi na terenie województwa zachodniopomorskiego.

Decyzja o ustaleniu lokalizacji inwestycji w zakresie terminalu ustala przede wszystkim lokalizację przedsięwzięć. W świetle art. 15 ust. 5 ustawy „ilekroć w przepisach Prawa budowlanego mowa jest o decyzji o warunkach zabudowy i zagospodarowania terenu, rozumie się przez to także decyzję o ustaleniu lokalizacji inwestycji w zakresie terminalu".

Wspomniany akt określa również między innymi (art. 10 ustawy) warunki techniczne realizacji inwestycji, warunki wynikające z potrzeb ochrony środowiska i ochrony zabytków, w tym dotyczące przeciwdziałania poważnym awariom przemysłowym, warunki ochrony przeciwpożarowej dla inwestycji, czy też wymagania dotyczące ochrony interesów osób trzecich. Decyzja o ustaleniu lokalizacji inwestycji w zakresie terminalu jest także wiążąca zarówno w zakresie procedury tworzenia miejscowych planów zagospodarowania przestrzennego, jak i przy wydawaniu decyzji o warunkach zabudowy, decyzji o ustaleniu lokalizacji inwestycji celu publicznego, decyzji o ustaleniu lokalizacji linii kolejowej oraz decyzji o zezwoleniu na realizację inwestycji drogowej (art. $10 \mathrm{i}$ art. 13 ust. 2-3 ustawy).

Decyzja o ustaleniu lokalizacji regionalnej sieci szerokopasmowej jest wydawana na podstawie ustawy z dnia 7 maja 2010 r. o wspieraniu rozwoju usług i sieci telekomunikacyjnych. ${ }^{22}$ Zgodnie $\mathrm{z}$ art. 2 ust. 1 pkt 1 tego aktu, siecią szerokopasmową jest sieć telekomunikacyjna służąca do zapewnienia szerokopasmowego dostępu do internetu. Dostęp określa się jako szerokopasmowy, jeżeli wydajność łącza nie jest czynnikiem ograniczającym możliwość uruchomienia aplikacji dostępnych w sieci. Jednocześnie art. 2 ust. 1 pkt 2 definiuje sieć regionalną jako sieć szerokopasmową realizowaną przez jednostki samorządu terytorialnego, porozumienie, związek lub stowarzyszenie jednostek samorządu terytorialnego, porozumienie komunalne, fundację, której fundatorem jest jednostka samorządu terytorialnego, spółkę kapitałową lub spółdzielnię z udziałem jednostki samorządu terytorialnego, koncesjobiorcę w rozumieniu ustawy z dnia 9 stycznia 2009 r. o koncesji na roboty budowlane lub usługi ${ }^{23}$ albo przez partnera prywatnego w rozumieniu ustawy $\mathrm{z}$ dnia 19 grudnia 2008 r. o partnerstwie publiczno-prywatnym ${ }^{24}$ w ramach programów operacyjnych.

Celem decyzji o ustaleniu lokalizacji regionalnej sieci szerokopasmowej jest lokalizacja takiej sieci i określenie jej podstawowych parametrów. Dotyczy to między innymi (art. 54 ust. 2 ustawy) warunków technicznych realizacji przedsięwzięcia, 
uwarunkowań wynikających z przepisów odrębnych czy wreszcie ograniczeń w korzystaniu z nieruchomości niezbędnych do realizacji regionalnej sieci szerokopasmowej, o ile jest to wymagane. W świetle art. 59 ust. 2 cytowanej ustawy ,ilekroć w odrębnych przepisach, w tym w przepisach ustawy z dnia 7 lipca 1994 r. - Prawo budowlane, jest mowa o decyzji o warunkach zabudowy i zagospodarowania terenu lub o decyzji o ustaleniu lokalizacji inwestycji celu publicznego, rozumie się przez to także decyzję o ustaleniu lokalizacji regionalnej sieci szerokopasmowej”.

Warto wreszcie wspomnieć o wydawanej na podstawie art. 7 ustawy z dnia 29 czerwca 2011 r. o przygotowaniu i realizacji inwestycji w zakresie obiektów energetyki jądrowej oraz inwestycji towarzyszących ${ }^{25}$ decyzji o ustaleniu lokalizacji inwestycji w zakresie budowy obiektu energetyki jądrowej. Obiektem energetyki jądrowej (art. 2 pkt 2 ustawy) jest elektrownia jądrowa lub działający na potrzeby energetyki jądrowej:

a) zakład wzbogacania izotopowego,

b) zakład wytwarzania paliwa jądrowego,

c) zakład przerobu wypalonego paliwa jądrowego,

d) przechowalnik wypalonego paliwa jądrowego,

e) obiekt do przechowywania odpadów promieniotwórczych,

f) zakład do wydobywania rud uranu i toru ze złóż i do ich wstępnego przetwarzania.

Pod pojęciem inwestycji towarzyszącej należy zaś rozumieć (art. 2 pkt 1 ustawy) inwestycję w zakresie budowy lub rozbudowy sieci przesyłowych w rozumieniu art. 3 pkt 11a ustawy z dnia 10 kwietnia 1997 r. - Prawo energetyczne (Dz.U. z 2006 r. Nr 89, poz. 625, z późn. zm.) koniecznych do wyprowadzenia mocy z elektrowni jądrowej lub inną inwestycję niezbędną do wybudowania lub zapewnienia prawidłowej eksploatacji obiektu energetyki jądrowej.

Podstawową funkcją decyzji o ustaleniu lokalizacji inwestycji w zakresie budowy obiektu energetyki jądrowej jest określenie nieruchomości objętych inwestycją w zakresie budowy obiektu energetyki jądrowej, w tym linii rozgraniczających obszar inwestycji, warunków technicznych jej realizacji, warunków wynikających z potrzeb ochrony środowiska i ochrony zabytków oraz ochrony przeciwpożarowej. Przy wydawaniu analizowanego aktu nie mają, co do zasady, zastosowania przepisy o planowaniu i zagospodarowaniu przestrzennym, jednakże wiąże ona właściwe organy przy sporządzaniu studium uwarunkowań i kierunków zagospodarowania przestrzennego oraz miejscowych planów zagospodarowania przestrzennego. 
VI. Jak widać, ustawodawstwo polskie przewiduje możliwość wydawania znacznej ilości aktów administracyjnych wprowadzających szczególny tryb postępowania w sprawie lokalizacji oraz określania warunków realizacji przedsięwzięć mających charakter inwestycji celu publicznego. Przeprowadzona tu, ze względu na objętość artykułu, dość pobieżna analiza pozwala na wyciągnięcie kilku wniosków.

Przyczyną wprowadzenia szczególnych rozwiązań dotyczących realizacji niektórych inwestycji o charakterze publicznym bez wątpienia jest chęć przyśpieszenia i uproszczenia procedur wydawania zezwoleń ich dotyczących. Przedsięwzięcia te, ze względu na swój charakter, muszą być realizowane w szczególnym trybie. Służą one bowiem nie tylko inwestorowi, ale najczęściej ogółowi społeczeństwa. Nie bez znaczenia jest również rola, jaką wspomniane inwestycje odgrywają dla szeroko rozumianej gospodarki narodowej.

Przedmiotem regulacji wydawanych na podstawie „specustaw” zezwoleń na realizację inwestycji nie jest oczywiście tylko sama ich lokalizacja. Określają one najczęściej szereg innych kwestii związanych z określeniem szczegółowych warunków realizacji przedsięwzięcia. Dotyczy to przede wszystkim aspektów technicznych, wymagań wynikających z potrzeb ochrony środowiska, ochrony dóbr kultury oraz potrzeb obronności państwa, czy ochrony uzasadnionych interesów osób trzecich. Część zezwoleń wydawanych na podstawie „specustaw” skutkuje wreszcie wywłaszczeniem nieruchomości, wskazanych w decyzji. Najbardziej znanym i budzącym kontrowersje przykładem jest decyzja o zezwoleniu na realizację inwestycji drogowej, wydawana na podstawie ustawy o szczególnych zasadach przygotowania i realizacji inwestycji w zakresie dróg publicznych. Zgodnie z jej art. 12 z dniem, w którym decyzja o zezwoleniu na realizację inwestycji drogowej stała się ostateczna, nieruchomości lub ich części niezbędne do realizacji inwestycji stają się własnością odpowiednio Skarbu Państwa albo jednostek samorządu terytorialnego. Przepisy powyższe, a zwłaszcza ograniczenie możliwości weryfikacji ostatecznego zezwolenia w drodze tzw. trybów „nadzwyczajnych” oraz możliwości zaskarżenia do sądu administracyjnego stały się nawet przedmiotem skargi do Trybunału Konstytucyjnego. Ten jednak, w wyroku z dnia 16 października 2012 r. (K 4/2010) ${ }^{26}$ uznał, iż zaskarżone przepisy nie naruszają konstytucji. Trybunał zwrócił uwagę, iż „,echą postępowania związanego z przygotowywaniem inwestycji liniowych, takich jak budowa dróg, jest wkraczanie inwestora w strukturę stosunków własnościowych, cechujących się w Polsce znacznym rozdrobnieniem. Prowadzi to do odejścia od indywidualizacji postępowania administracyjnego. Przy założonym przebiegu drogi wybór działek, przez które ma przebiegać, jest bardzo ograniczony albo wręcz nie istnieje, a wypadnięcie choćby jednej z grupy wywłaszczanych nieruchomości może unicestwić całą inwestycję. Racjonalny ustawodawca zobowiązany był 
to założenie uwzględnić i znajduje ono odzwierciedlenie w art. 31 ust. 1 i 2, które ograniczają zakres zaskarżenia decyzji, przyczyniając się zarówno do przyspieszenia postępowania, jak i wzmocnienia skuteczności decyzji, a w konsekwencji - służą zabezpieczeniu niezakłóconej realizacji inwestycji. Dlatego rozpoczęcie budowy drogi ustawodawca traktuje jako moment, w którym ostateczna decyzja o zezwoleniu na jej budowę wywołuje nieodwracalne skutki prawne i od tej chwili nie dopuszcza do stwierdzenia jej nieważności”.

Podniesione uwagi dotyczące innych skutków prawnych wywoływanych przez „szczególne” substytuty planowania przestrzennego mają charakter informacyjny. Nie były one przedmiotem analizy dokonanej w tym artykule, wskazują jednak na szereg trudności i wieloaspektowość omawianej problematyki.

Przewidziane przez ustawy szczególne ,substytuty” planowania przestrzennego bez wątpienia upraszczają proces lokalizacji inwestycji o charakterze publicznym. $\mathrm{W}$ polskim systemie prawnym pojawiły się one stosunkowo niedawno, jednakże stają się coraz popularniejszym instrumentem usprawniającym proces realizacji niektórych przedsięwzięć. Warto zwrócić uwagę, iż począwszy od 2003 r. zostało wydanych już osiem ustaw przewidujących tego typu regulacje. W analizowanym zakresie (lokalizacji przedsięwzięć) stanowią one bez wątpienia środek pozwalający zniwelować niedoskonałości polskiego systemu planowania przestrzennego.

Jak się wydaje, w obowiązującym stanie prawnym sprawność procesu inwestycyjnego (w zakresie przedsięwzięć regulowanych wyżej omówionymi decyzjami) może zostać zachowana jedynie przy wykorzystaniu zezwoleń wydawanych na podstawie ustaw szczegółowych. Następującej w ten sposób „dekompozycji” systemu planowania przestrzennego i inwestycyjnego opartego o przepisy ustawy o planowaniu i zagospodarowaniu przestrzennym oraz ustawy prawo budowlane nie należy oceniać negatywnie. Oczywiście, przy stosowaniu przepisów szczególnych pojawia się wiele wątpliwości interpretacyjnych, często wymagających interwencji ustawodawcy. Znaczącą rolę w tym zakresie może również odegrać doktryna prawa.

Artykuł niniejszy nie stanowi głębokiej analizy podstaw wydawania zezwoleń na podstawie ustaw szczególnych. Sygnalizuje jedynie, iż pełnią one między innymi funkcję szczególnego rodzaju substytutów planowania przestrzennego. Konieczne jest podjęcie szerokich badań w tym zakresie. Niestety, w nauce prawa trudno znaleźć głębsze opracowania dotyczące charakteru wspomnianych rozwiązań. 
PRACTITULAR SUBSTITUTES OF SPATIAL PLANNING

Key words: local area development plan, public aim imvestment, real estate expropriation.

Lack of general planning duty along with long time required for conduction of procedures concerning passing (introducing changes) in local area development plans lead to substantial difficulties in making location of numerous investment of public nature (public aim investments). Unfortunately the Act of 27th March 2003 on spatial planning and development (Journal of Laws of 2012 item 647 with subsequent changes) does not foresee any particular solutions.

Therefore legislator decided to introduce particular regulations within this field. Decisions which approve of carrying out respective investments determining their location are to be solution to the above mentioned problems. The most frequently spatial planning and development regulations are not applied while issuing these decisions, although sometimes they are binding while making local plans, or issuing decisions on development conditions, as well as area development plans. Decisions which are issued within this scope can be determined as particular substitutes of spatial planning. However, it is worth to underline that the above mentioned acts determine also number of different issues connected with conditions of carrying out plans and can result in real estate expropriation at the area of planned undertaking, or at last some of them constitute consent to its construction. 